\title{
Association and Release of the Amyloid Protein Precursor of Alzheimer's Disease from Chick Brain Extracellular Matrix
}

\author{
D. H. Small, ${ }^{1,3}$ V. Nurcombe, ${ }^{2}$ R. Moir, ${ }^{1,3}$ S. Michaelson, ${ }^{1,3}$ D. Monard, ${ }^{4}$ K. Beyreuther, ${ }^{5}$ and C. L. Masters ${ }^{1,3}$ \\ Departments of ${ }^{1}$ Pathology and ${ }^{2}$ Anatomy, University of Melbourne, Parkville, Victoria 3052, Australia, ${ }^{3}$ The Mental Health \\ Research Institute of Victoria, Parkville, Victoria 3052, Australia, ${ }^{4}$ Friedrich Miescher Institut, Basel, Switzerland, and \\ ${ }^{5}$ Centre for Molecular Biology, University of Heidelberg, Heidelberg, Germany
}

\begin{abstract}
The amyloid protein precursor (APP) of Alzheimer's disease was found to bind saturably $\left(K_{d}=60 \mathrm{~nm}\right)$ to embryonic chick brain extracellular matrix (ECM). The binding of APP to ECM was not inhibited by $10 \mu \mathrm{g} / \mathrm{ml}$ heparin or heparan sulfate. However, pretreatment of cells with $1 \mathrm{~mm}$ 4-methylumbelliferyl- $\beta-D-x y l o s i d e$, an inhibitor of proteoglycan biosynthesis, reduced the number of APP binding sites on the ECM by $80 \%$. The binding of APP to ECM was also inhibited by pretreatment with chlorate, an inhibitor of glycan sulfation, and heparitinase, which digests the carbohydrate component of heparan sulfate proteoglycans. These results suggest that APP binds with high affinity to one or more heparan sulfate proteoglycans. Acidic and basic fibroblast growth factor (FGF) also bound to chick ECM. When ECM was incubated with a protease associated with the enzyme AChE (AChEAP), APP and acidic FGF were released intact from the matrix. The AChE-AP was at least 100-fold more potent in releasing APP from ECM than other trypsin-like proteases (trypsin, plasmin, thrombin). The action of the AChE-AP was inhibited by glia-derived nexin (protease nexin I) and by human brain APP at low nanomolar concentrations. These results suggest that in vivo an AChE-AP may cleave ECM proteins to regulate the availability of soluble APP or other factors bound to the ECM.
\end{abstract}

The movement of neuronal growth cones and their interaction with components of the extracellular matrix (ECM) are regulated by the secretion of specific proteases and protease inhibitors (Monard, 1987, 1988). Detachment of the plasma membrane from the ECM may be mediated by the action of proteases that arc sccreted from cells into the extraccllular cnvironment. Early studies by Krystosek and Seeds (1981a,b, 1984) and Pittman (1985) demonstrated that urokinase-like (plasminogen activator) activities may be released by growth cones and may be important for cerebellar granule neuron migration.

The secretion of protease inhibitors regulates interactions between growth cones and the ECM. A glia-derived neurite-promoting factor, identified as a serine protease inhibitor (Guenther

\footnotetext{
Received Oct. 21, 1991; revised Apr. 6, 1992; accepted May 11, 1992

This work was supported by grants from the National Health and Medical Research Council of Australia, the Aluminium Development Corporation of Australia, and the Victorian Health Promotion Foundation. K.B. is supported by grants from the Deutsche Forschungsgemeinschaft and the Bundesministerium für Forschung und Technologie.

Correspondence should be addressed to Dr. David H. Small, Department of Pathology, University of Melbourne, Parkville, Victoria 3052, Australia.

Copyright $(\mathcal{1} 1992$ Society for Neuroscience $0270-6474 / 92 / 124143-08 \$ 05.00 / 0$
}

et al., 1985), has been called glia-derived nexin (GDN) (Gloor et al., 1986). It has since been shown that protease nexin I (PN I) has the same primary sequence as GDN (McGrogan et al., 1988). PN I and PN I-protease complexes bind to components of the ECM (Rovelli et al., 1990). The importance of such interactions is supported by the fact that PN I inhibits the degradation of isolated endothelial cell matrix by fibrosarcoma cells (Bergman et al., 1986).

It has been suggested that ECM may serve as a reservoir for growth factors and other proteins, as long-term effects of basic fibroblast growth factor (FGF) on endothelial cells are dependent upon the binding of basic FGF to ECM (Flaumenhaft et al., 1989; Vlodavsky et al., 1991). The secretion of proteases from the growth cone may be required for the release of growth factors from the ECM (Saksela and Rifkin, 1990). Incubation of plasmin or thrombin with ECM releases basic FGF that is bound to matrix heparin sulfate proteoglycans. The $\beta \mathrm{A} 4$ amyloid protein precursor (APP) associated with Alzheimer's disease (Kang et al., 1987) is also thought to bind to components of the ECM (Klier et al., 1990), where it may interact with heparan sulfate proteoglycans (Schubert et al., 1989a,b; Narindrasorasak et al., 1991). However, APP may also bind to other ECM components. Little is known about whether APP can be released from ECM by the action of secreted proteases.

The developing chick embryo provides an excellent system for studying neurite outgrowth and ECM interactions (Perris and Bronner-Fraser, 1989). Studies by Layer (1983) and Layer et al. $(1987,1988)$ have demonstrated that $\mathrm{AChE}$ is expressed at a precise stage in the development of chick brain neuroblasts, just prior to neurite outgrowth. There is evidence that the expression of $\mathrm{AChE}$ early in development is important for neurite outgrowth (Small, 1990). A role for AChE in cell adhesion has been suggested (Krejci et al., 1991) based on the presence of a cell adhesion epitope (HNK-1) on the surface of the protein (Bon et al., 1987), and on the amino acid sequence homologies between cholinesterases and the cell adhesion proteins glutactin (Olson et al., 1990) and neurotactin (Barthalay et al., 1990; De la Escalara et al., 1990).

We have demonstrated that a protease activity is associated with AChE purified from fetal bovine serum (Small, 1988) or eel electric organ (Small et al., 1987). This protease activity is attributable to a protein that binds to AChE and that has the properties of an "APP secretase" (Small et al., 1991), the enzyme that is thought to release APP from the surface of cells. Released APP may in turn bind to the ECM and influence the course of neurite outgrowth (Schubert et al., 1989a). 
In order to identify prospective proteases that may cleave ECM, we have examined the ability of the AChE-associated protease (AChE-AP) to release APP and FGF from ECM produced by dissociated cultures of embryonic chick brain. We have also examined the ability of protease inhibitors such as PN I and APP itself, the secreted form of which is PN II (Oltersdorf et al., 1989; Van Nostrand et al., 1989), to inhibit this action of the AChE-AP.

\section{Materials and Methods}

Materials. APP was purified from human brain by a combination of heparin-Sepharose, ion-exchange, and hydrophobic interaction chromatography (Moir et al., in press). Acidic and basic fibroblast growth factor (FGF) were from Amersham Australia Pty. Ltd. (North Ryde, Australia). Recombinant rat glia-derived nexin (PN I) was produced in Saccharomyces cerevisiae strain GRF18 under the control of the PHO5 promoter and purified from a cellular extract by heparin-Sepharose and ion-exchange chromatography (Sommer et al., 1989). Heparan sulfate was purified from conditioned medium of $2.3 \mathrm{D}$ cells according to the method of Hassell et al. (1980). Heparin (grade I, $176 \mathrm{IU} / \mathrm{mg}$ ), 4-methylumbelliferyl- $\beta$-D-xyloside, high-purity collagenase (typc VII), plasmin, and heparitinase were from Sigma Chemical Co. (St. Louis, MO). Highpurity-grade bovine thrombin was from ICN Flow (Sydney, Australia). Bovine pancreatic trypsin was purchased from Boehringer-Mannheim (Sydney, Australia).

Purification of AChE-associated protease. The AChE-associated protease (AChE-AP) was purified from a commercial preparation of eel electroplax AChE by affinity chromatography on edrophonium-Sepharose and by size-exclusion high-performance liquid chromatography (SE-HPLC) on TSK 400SW as previously described (Small et al., 1987). To remove any contaminating trypsin-like enzymes (those not associated with $\mathrm{AChE}$ ) from the preparation, crude eel AChE (Sigma type $\mathrm{V}-\mathrm{S})$ was passed across a column $(20 \mathrm{ml}$ bed volume $)$ of benzamidineSepharose (Pharmacia) before further purification on edrophonium-Sepharose. The AChE-AP was also purified from fetal bovine serum by affinity chromatography and SE-HPLC (S. Michaelson and D. H. Small, unpublished observations).

Iodination of $A P P$ and $F G F$. APP and acidic and basic FGF were iodinated using chloramine $T$ as described by Hunter and Greenwood (1962) with a few minor modifications. Protein $(30 \mu \mathrm{g})$ was incubated with $0.5 \mathrm{mCi}$ of carrier-free ${ }^{125} \mathrm{I}$-sodium iodide and $60 \mu \mathrm{g}$ of chloramine $\mathrm{T}$ for $5 \mathrm{~min}$ in $50 \mathrm{~mm}$ sodium phosphate buffer, $\mathrm{pH} 7.4$. The reaction was stopped with $0.12 \mathrm{ml}$ of sodium metabisulfite $(0.6 \mathrm{mg} / \mathrm{ml})$ containing $1 \mathrm{~m}$ sodium chloride, $0.1 \%(\mathrm{w} / \mathrm{v})$ bovine serum albumin, and $1 \%(\mathrm{w} / \mathrm{v})$ potassium iodide in $50 \mathrm{~mm}$ sodium phosphate buffer, $\mathrm{pH} 7.4$. Labeled protein was separated from free iodide by desalting on a BioRad Econo-Pac 10DG column equilibrated with $50 \mathrm{~mm}$ phosphate buffer containing $1 \%(\mathrm{w} / \mathrm{v})$ bovine serum albumin. Preparations of labeled APP and basic and acidic FGF had specific radioactivities of approximately $20,000 \mathrm{dpm} / \mathrm{ng}$ protein, $30,000 \mathrm{dpm} / \mathrm{ng}$ protein, and 26,000 $\mathrm{dpm} / \mathrm{ng}$ protein, respectively.

Preparation of embryonic chick brain ECM. Brains were removed from 10-d-old chick embryos, freed of meninges, and then minced finely and incubated with trypsin-Versene for $0.5 \mathrm{hr}$ at $37^{\circ} \mathrm{C}$. Cells were dissociated by trituration and then plated at a density of $10^{5}$ cells per 16 $\mathrm{mm}^{2}$ well in a 24-well culture plate in Dulbecco's Modified Eagle's medium (DMEM) containing 10\% fetal calf serum. The cells were maintained in culture until confluent and then cultured in DMEM containing $1 \%$ fetal calf serum for 7-10 d. Cultures were washed twice with phosphate-buffered saline (PBS) and then treated with lysis buffer $(0.5 \%$ Triton X-100, $20 \mathrm{~mm} \mathrm{NH}_{4} \mathrm{OH}$ in PBS) for approximately $10 \mathrm{~min}$ on an orbital shaker until cells were observed to rupture. The lysis buffer was removed and the plates washed twice with PBS. The resulting ECM preparation was stored in $1 \mathrm{ml} /$ well PBS at $4^{\circ} \mathrm{C}$ until ready to use.

Labeling of cultures with ${ }^{35} S$-sulfate. Five days before harvesting ECM, cultures were treated with either $10 \mathrm{~mm}$ chlorate or $1.0 \mathrm{~mm}$ 4-methylumbelliferyl- $\beta$-D-xyloside (xyloside). The effect of xyloside on heparan sulfate proteoglycan synthesis was monitored by incorporation of ${ }^{35} \mathrm{~S}$-labeled sulfate. During the last $24 \mathrm{hr}$ of culture, cultures were incubated with $100 \mu \mathrm{Ci} / \mathrm{ml}{ }^{35} \mathrm{~S}$-sulfate (Du Pont-New England Nuclear). After incuhation, the medium, was collected and dialyzed against three changes of PBS. ECM was prepared as before and extracted with $0.25 \mathrm{ml}$ of $2 \%$ $(\mathrm{w} / \mathrm{v})$ sodium dodecyl sulfate in $0.1 \mathrm{~m}$ Tris- $\mathrm{HCl}, \mathrm{pH} 7.5$. The incor- poration of labeled sulfate into low-molecular-weight glycosaminogly cans and high-molecular-weight proteoglycans was determined by sizeexclusion chromatography as described by Saskela et al. (1988).

Incubation of ECM with labeled proteins and enzymes. ECM was incubated for $1 \mathrm{hr}$ at $37^{\circ} \mathrm{C}$ with $1.0 \mathrm{nCi}$ of labeled APP or acidic or basic FGF in $1.0 \mathrm{ml}$ of $1.0 \%(\mathrm{w} / \mathrm{v})$ bovine serum albumin in PBS per well. After incubation, the label was removed and each well washed twice with $1.0 \mathrm{ml}$ PBS. The ability of proteases to release the labeled protein from the ECM was examined by incubating each well with 0.2 $\mathrm{ml}$ of protease $\left(0-10^{4} \mathrm{ng} / \mathrm{ml}\right.$ in PBS) for $1 \mathrm{hr}$ at $37^{\circ} \mathrm{C}$. After incubation, the solution was collected and counted for radioactivity.

$S D S-P A G E$ and autoradiography. Samples $(10 \mu \mathrm{l})$ were analyzed by $12.5 \%$ or $15 \%$ polyacrylamide gel electrophoresis in the presence of $0.1 \%$ sodium dodecyl sulfate (SDS-PAGE) (Laemmli, 1970). The gels were either stained with silver reagent (Oakley et al., 1980) or dried under vacuum, and the iodinated proteins were detected by autoradiography using Kodak XAR-5 film.

Western blotting of APP in brain. APP immunoreactivity was demonstrated in chick brain by SDS-PAGE followed by Western blotting. Embryonic chick brains were weighed and then homogenized in an equal volume of $50 \mathrm{~mm}$ Tris- $\mathrm{HCl}, \mathrm{pH} 7.4$, using a Branson sonicator at setting $3(50 \%$ intermittency). Homogenates $(100 \mu \mathrm{l})$ were heated in a boiling water bath for $15 \mathrm{~min}$ in the presence of $100 \mu \mathrm{l}$ of SDS-PAGE sample buffer (Laemmli, 1970) before SDS-PAGE. Following electrophoretic transfer onto nitrocellulose, APP was detected by staining with a mouse monoclonal antibody (22C11) (Boehringer-Mannheim) directed against an epitope on the ectodomain of the APP molecule (Weidemann et al., 1989; Small et al., 1991).

Assays. Cholinesterase activity was assayed by the method of Ellman et al. (1961) using acetylthiocholine as substrate. Butyrylcholinesterase (BChE) activity was defined as esterase activity that was not inhibited by the specific AChE inhibitor BW284c51. For the assay of cholinesterase activity in embryonic chick brains, AChE and BChE were extracted by homogenizing each brain as described for measurement of APP immunoreactivity, except that the homogenization buffer contained, in addition, $2 \mathrm{~m}$ sodium chloride and $2 \%(\mathrm{v} / \mathrm{v})$ Triton X-100. Protein was assayed by the method of Bradford (1976) using bovine serum albumin as standard.

\section{Results}

\section{Expression of cholinesterases and APP in embryonic chick brain}

As the cholinesterases and APP have been strongly implicated in neurite outgrowth, we examined the expression of these proteins during periods at which neurite outgrowth becomes maximal in the developing chick brain. Embryonic chick brains (day 4 to day 13) were extracted at high ionic strength in the presence of Triton X-100, and the extracts were assayed for AChE and $\mathrm{BChE}$ activity. Both $\mathrm{AChE}$ and $\mathrm{BChE}$ were detectable from the earliest embryonic age (4 d) (Fig. 1). The amount of activity per gram of brain began to increase after day 7 , during the main period of neurite outgrowth in the developing chick brain. AChE activity increased approximately fourfold between days 7 and 9. BChE activity increased about fourfold between days 8 and 13.

The amount of APP in the developing chick brain was assessed by Western blotting with monoclonal antibody $22 \mathrm{C} 11$, which recognizes an epitope close to the N-terminus of APP. Multiple immunoreactive bands were identified in the chick brain (Fig. 2), but the relative molecular masses $\left(M_{r}\right)$ of the major APP-immunoreactive polypeptides (between $90-130 \mathrm{kDa}$ ) were similar to those found previously in studies of $\triangle P P$ in other tissues (Weidemann et al., 1989; Bush et al., 1990). Like AChE, APP was detectable during the earliest stages of embryonic brain development, and increased between embryonic days 7 and 9. A major band of $42 \mathrm{kDa}$ was also detected by the monoclonal antibody. The expression of this $42 \mathrm{kDa}$ protein did not correlate with other APP-immunoreactive bands, sug- 

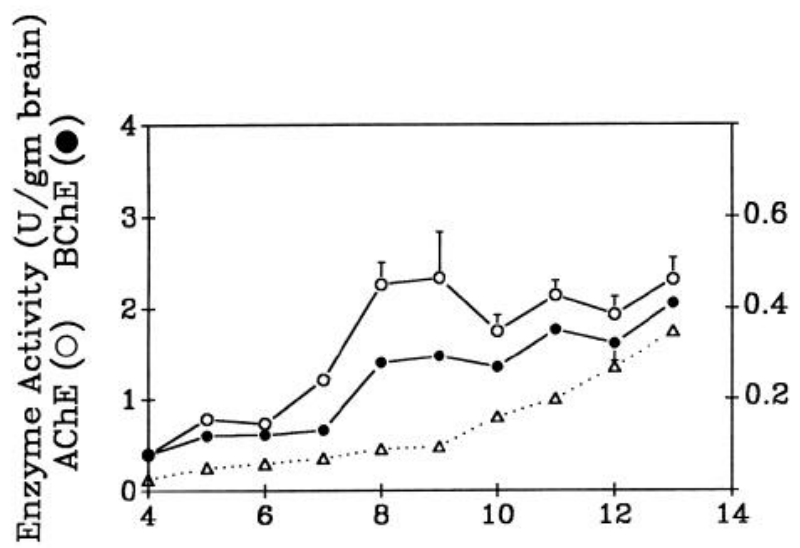

Embryonic Age (d)

Figure 1. Expression of $\mathrm{AChE}$ and $\mathrm{BChE}$ activities in embryonic chick brain. Brains were dissected from embryonic chicks and weighed, and then the cholinesterases were solubilized by homogenization with Triton $\mathrm{X}-100$ in the presence of high salt. AChE and BChE activities were measured using acetylthiocholine as substrate. The amount of $\mathrm{AChE}$ activity was defined as the difference between the total cholinesterase activity and the amount of BChE activity (measured in the presence of the specific AChE inhibitor BW284c51). Units of activity are micromoles of acetylthiocholine hydrolyzed per min at $30^{\circ} \mathrm{C}$. Error bars show SEM.

gesting that it may be an unrelated cross-reactive protein. Preabsorption of the $22 \mathrm{Cl1}$ antibody with purified APP completely blocked the staining of all bands including the $42 \mathrm{kDa}$ band, indicating that the polypeptides recognized by the monoclonal antibody were all fragments of APP or at least shared the same epitope as APP.

\section{Binding of acidic $F G F$, basic $F G F$, and APP to ECM}

To study the action of the AChE-AP on ECM, we first examined the ability of FGF and APP to bind to embryonic chick brain

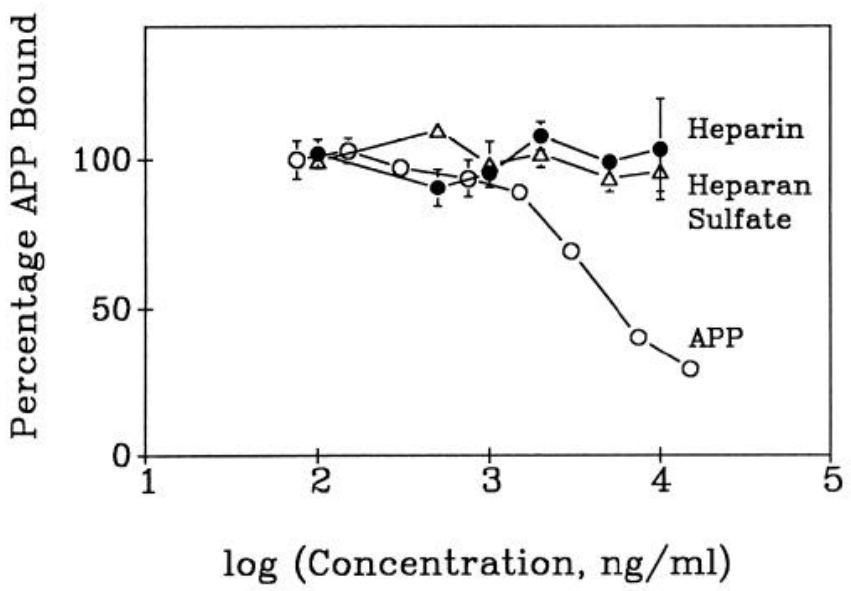

Figure 3. Effect of APP $(O)$, heparin ( $(\bullet)$, and heparan sulfate $(\triangle)$ on the binding of ${ }^{125}$ I-labeled APP to embryonic chick brain ECM on a 24 well culture plate. All points show the mean of three determinations, with error bars showing the SEM. Transformation of the APP binding data by Scatchard plot analysis yielded an equilibrium dissociation constant $\left(K_{d}\right)$ for the binding of APP to ECM of $60 \mathrm{nM}$ and a maximum binding capacity $\left(B_{\max }\right)$ of $0.38 \mathrm{pmol}$ of APP per $\mathrm{cm}^{2}$ of ECM. For the purposes of calculation, the $M_{r}$ of APP was assumed to be 80,000 . One hundred percent bound corresponded to $1608 \mathrm{cpm}$ of ${ }^{125} \mathrm{I}-\mathrm{APP}$ bound to ECM.

ECM. APP, acidic FGF, and basic FGF were iodinated, and then $1.0 \mathrm{nCi}$ of labeled protein (approximately $100 \mathrm{pg}$ ) was incubated with ECM prepared in 24-well culture dishes. Approximately $3 \%$ of the labeled APP, $6 \%$ of the acidic FGF, and $9 \%$ of the basic FGF remained bound to the matrix after repeated washings with PBS. The labeled proteins were released from the matrix in the presence of $2 \%(w / v)$ SDS. To study the specificity of the interaction between APP and ECM, we examined the ability of unlabeled APP, heparin, and heparan sulfate to compete for binding (Fig. 3). Incubation with non-

\section{Embryonic Age (d)}

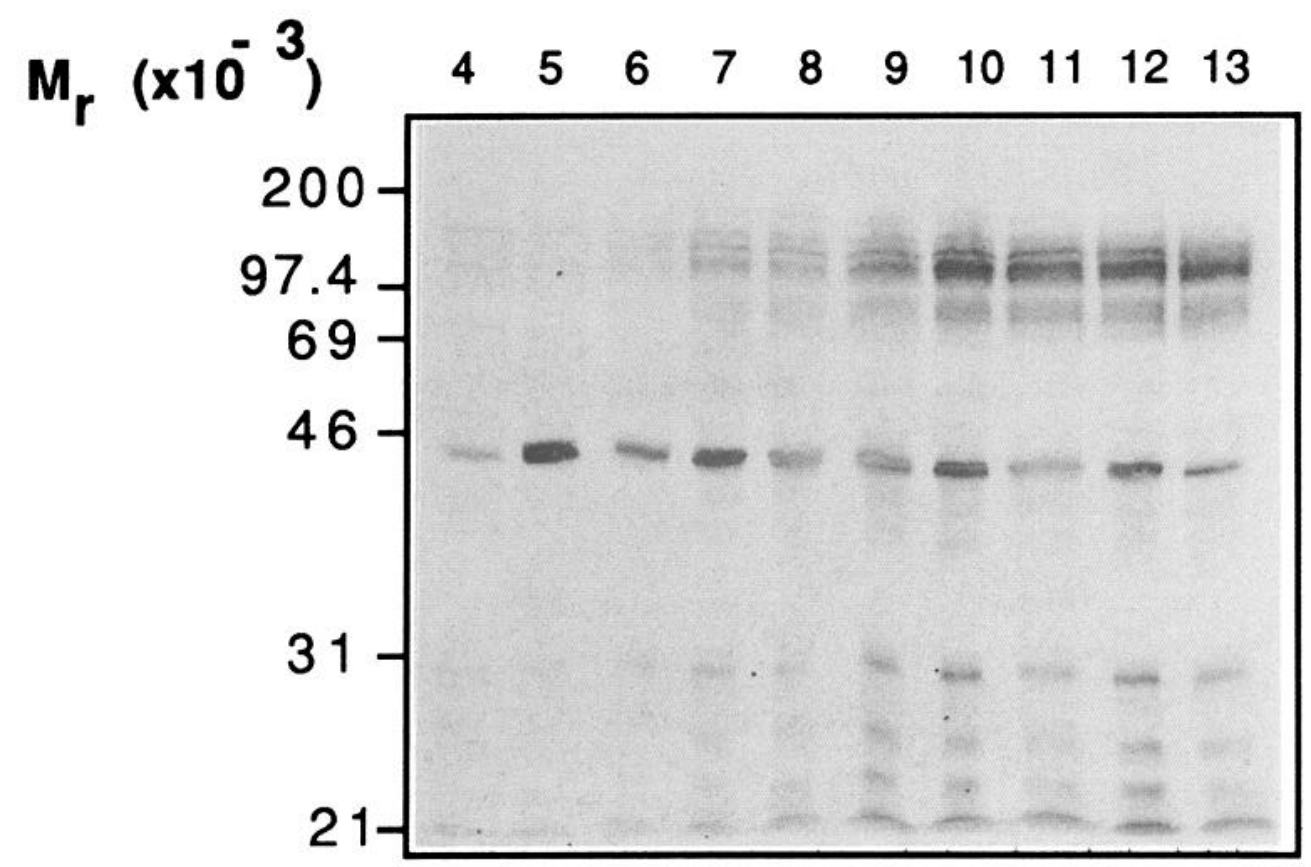

Figure 2. Expression of APP-immunoreactive proteins in embryonic chick brain as measured by Western blotting with a mouse monoclonal antibody (22C11). The figure shows the $M_{r}$ of standard proteins (myosin, $200 \mathrm{~K}$; phosphorylase, $97.4 \mathrm{~K}$; bovine serum albumin, $69 \mathrm{~K}$; ovalbumin, $46 \mathrm{~K}$; carbonic anhydrase, $31 \mathrm{~K}$; soybean trypsin inhibitor, $21 \mathrm{~K}$ ). Each lane contains a sample of protein derived from an equivalent amount $(10 \mathrm{mg}$ wet weight) of embryonic chick brain. 
Table 1. Inhibition of ${ }^{35} \mathrm{~S}$-sulfate incorporation into proteoglycans and glycosaminoglycans produced by embryonic chick brain cells in culture

\begin{tabular}{|c|c|c|c|}
\hline \multirow[b]{2}{*}{ Fraction } & \multicolumn{3}{|c|}{ Incorporation of sulfatc $\left(\mathrm{cpm} / 10^{5}\right.$ cclls) } \\
\hline & No xyloside & Xyloside (1 mm) & $\begin{array}{l}\% \\
\text { Control }\end{array}$ \\
\hline \multicolumn{4}{|l|}{ Medium } \\
\hline Proteoglycans & $67,600 \pm 9800$ & $12,800 \pm 1600$ & 19 \\
\hline Glycosaminoglycans & $80,200 \pm 2200$ & $631,000 \pm 40,000$ & 787 \\
\hline \multicolumn{4}{|l|}{ ECM } \\
\hline Proteoglycans & $16,300 \pm 1600$ & $4730 \pm 380$ & 29 \\
\hline
\end{tabular}

Cultured chick brain cells were labeled with $100 \mu \mathrm{Ci} / \mathrm{ml}$ of ${ }^{35} \mathrm{~S}_{-} \mathrm{SO}_{4}$ for $24 \mathrm{hr}$ in the presence or absence of xyloside. The level of incorporation of label into proteoglycans and glycosaminoglycans in the medium and ECM was measured by SE-HPLC as described by Saksela et al. (1988). Data are means \pm SEM $(n=3)$.

radioactive APP resulted in a dose-dependent inhibition of binding of ${ }^{125}$ I-APP. Scatchard analysis of the binding (not shown) resulted in an equilibrium dissociation constant $\left(K_{d}\right)$ of $5 \mu \mathrm{g} / \mathrm{ml}$ or $60 \mathrm{~nm}$ (assuming an approximate molecular weight for the apoprotein form of APP of 80,000). Neither heparin nor heparan sulfate inhibited the binding at concentrations up to $10 \mu \mathrm{g} / \mathrm{ml}$.

We also examined the ability of APP to bind to ECM pretreated with agents that disrupt components of the ECM and compared the binding with that of acidic and basic FGF, which are known to bind heparan sulfate proteoglycans. Cultures of brain cells were incubated for $5 \mathrm{~d}$ with $1 \mathrm{~mm}$ xyloside, an inhibitor of proteoglycan synthesis (Carey et al., 1987), or $10 \mathrm{~mm}$ chlorate, an inhibitor of proteoglycan sulfation (Rapraeger et al., 1991). Xyloside pretreatment of cells resulted in a $70 \%$ inhibition of heparan sulfation as determined from the incorporction of radioactively labeled sulfate into ECM proteoglycans (Table 1). The binding of APP to ECM from cells pretreated with $1 \mathrm{mM}$ xyloside was approximately $80 \%$ lower than to control ECM. Xyloside pretreatment also reduced the binding of acidic and basic FGF by $60 \%$ and $70 \%$, respectively. Chlorate pretreatment reduced the binding of APP, acidic FGF, and basic FGF to ECM by $80 \%, 50 \%$, and $60 \%$, respectively.

The effect of enzymes that cleave components of the ECM on APP binding was also examined and compared with effects on acidic and basic FGF binding. The binding of APP, acidic FGF, and basic FGF to ECM was inhibited by approximately $80 \%$, $50 \%$, and $55 \%$, respectively, following incubation of the ECM with heparitinase $(10 \mathrm{mIU} / \mathrm{ml})$, which digests the carbohydrate moieties of heparan sulfate proteoglycans (Table 2). Collagenase $(100 \mu \mathrm{g} / \mathrm{ml})$ digestion of ECM significantly increased the number of APP binding sites on the matrix by $25 \%(P<0.01)$. Although the amount of acidic and basic FGF measured bound to the matrix was greater after collagenase treatment, the increase in binding was not statistically significant.

\section{Release of acidic FGF and APP from $E C M$ by $A C h E-A P$}

The ability of the AChE-AP to release bound acidic FGF and APP from ECM was examined. Incubation of ECM with eel or serum AChE-AP ( $1 \mathrm{ng} / \mathrm{ml}$ to $10 \mu \mathrm{g} / \mathrm{ml}$ ) resulted in the dosedependent release of label from the matrix (Fig. 4). To determine whether the labeled proteins were being released intact from the matrix, the released material was analyzed by SDS-PAGE followed by autoradiography. The $M_{r}$ of the iodinated APP and acidic FGF released by the AChE-AP was similar to that of the intact protein (Fig. 5), indicating that the iodinated proteins had not been cleaved to any major extent by the AChE-AP.

The actions of the AChE-AP in releasing APP from the ECM were compared with those of other proteases by examining the concentration dependence of the release of APP from the ECM (Fig. 6). The eel and serum AChE-APs were at least 100-fold more potent in their ability to release APP than other proteases that were tested (thrombin, plasmin, trypsin). The protein concentration of eel or serum AChE-AP required to produce halfmaximal release of APP from the ECM was between $10^{-8}$ and $10^{-7} \mathrm{gm} / \mathrm{ml}$. With the exception of plasmin, the proteases released all of the APP from the matrix at high concentrations

Table 2. Effect of pretreatment with xyloside, chlorate, and enzymes on binding of ${ }^{125}$ I-APP, ${ }^{125 I-a c i d i c}$ FGF, and "25I-basic FGF to chick brain ECM

\begin{tabular}{llcc} 
& \multicolumn{3}{l}{ Amount bound to ECM (cpm bound/well) } \\
\cline { 2 - 4 } Treatment & ${ }^{125}$ I-APP & ${ }^{125}$ I-acidic FGF & ${ }^{125}$ I-basic FGF \\
\hline Control & $676 \pm 34$ & $1875 \pm 104$ & $1262 \pm 113$ \\
Xyloside $(1 \mathrm{mM})$ & $136 \pm 8^{*}$ & $617 \pm 50^{*}$ & $519 \pm 87^{*}$ \\
Chlorate $(10 \mathrm{mM})$ & $126 \pm 13^{*}$ & $754 \pm 112^{*}$ & $642 \pm 42^{*}$ \\
Heparitinase $(10 \mathrm{mIU} / \mathrm{ml})$ & $132 \pm 24^{*}$ & $1021 \pm 146^{*}$ & $600 \pm 52^{*}$ \\
Collagenase $(100 \mu \mathrm{g} / \mathrm{ml})$ & $842 \pm 27^{*}$ & $2067 \pm 54$ & $1368+25$ \\
Thrombin $(100 \mu \mathrm{g} / \mathrm{ml})$ & $716 \pm 18$ & $1967 \pm 38$ & $1368 \pm 94$
\end{tabular}

Chick brain neurons were cultured in 24-well plastic dishes until confluent ( $2 \mathrm{~d}$ ) and then incubated for $5 \mathrm{~d}$ in the presence or absence of xyloside or chlorate. ECM was prepared from the cultures and treated with heparitinase, collagenase, or thrombin. ECM was then incubated with $1.0 \mathrm{nCi} /$ well of iodinated protein. The amount of radioactivity bound to the ECM was measured. Values are means \pm SEM $(n=4)$.

*, Significantly different $(P<0.05)$ from controls as determined by two-tailed Student's $t$-test. 

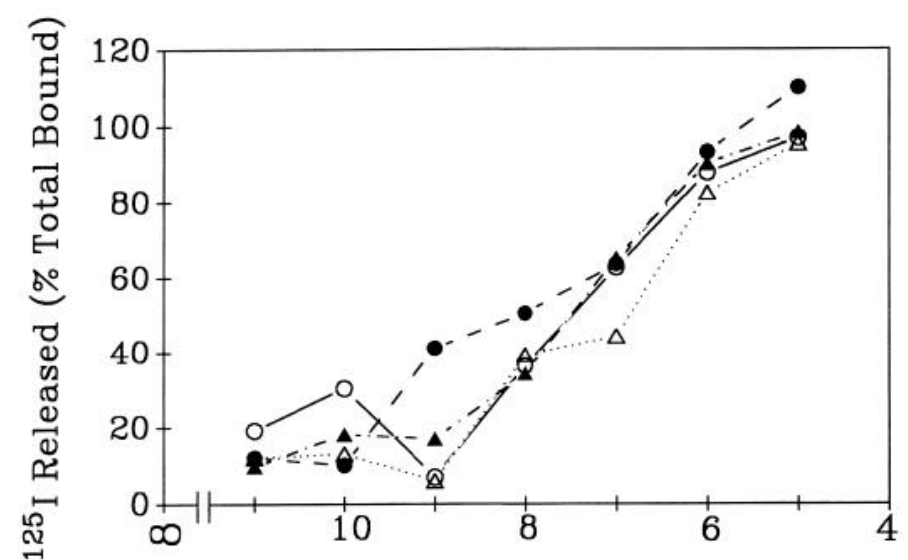

$$
-\log \text { (Concentration of } \mathrm{AChE}-\mathrm{AP}, \mathrm{gm} / \mathrm{ml} \text { ) }
$$

Figure 4. Effect of AChE-AP purified from fetal bovine serum $(O, \triangle)$ or eel electroplax organ $(\boldsymbol{\bullet}, \mathbf{\Delta})$ on the release of ${ }^{125}$ I-labeled APP $(\triangle, \mathbf{\Delta})$ or acidic FGF $(O, \bullet)$ from embryonic chick brain ECM. The figure shows a typical result obtained in three separate experiments. The amount released is shown as a percentage of the total amount of radioactivity bound prior to the addition of protcasc. Points represent the mean of two determinations. One hundred percent bound represented 1565 and $1888 \mathrm{cpm} /$ well for acidic FGF and APP, respectively.

$(0.1-1.0 \mathrm{mg} / \mathrm{ml})$. Incubations with similar concentrations of plasmin resulted in release of approximately $60 \%$ of the total bound APP, suggesting that APP may bind to sites on the ECM that are resistant to digestion by plasmin.

Inhibition by protease inhibitors. The specificity of the effect of AChE-AP on APP release from the ECM was tested further, by examining the ability of protease inhibitors to inhibit the release of APP from the matrix (Fig. 7). We found that inhibitors of the AChE-AP also inhibited the ability of the AChE-AP fraction to release APP from the ECM. Both PN I and APP were potent inhibitors of release even at concentrations below $10 \mathrm{~nm}$. The trypsin-like activities of serum and eel AChE-AP were also potently inhibited by PN I and APP (Fig. 8). In contrast, the broad-spectrum serine protease inhibitor soybean trypsin inhibitor weakly inhibited release of APP (Fig. 7) and only weakly inhibited the trypsin-like protease activity (Fig. 8) at high concentrations ( $>1 \mu \mathrm{M})$. Taken together, these results confirmed that the effect of the AChE-AP fractions in stimulating
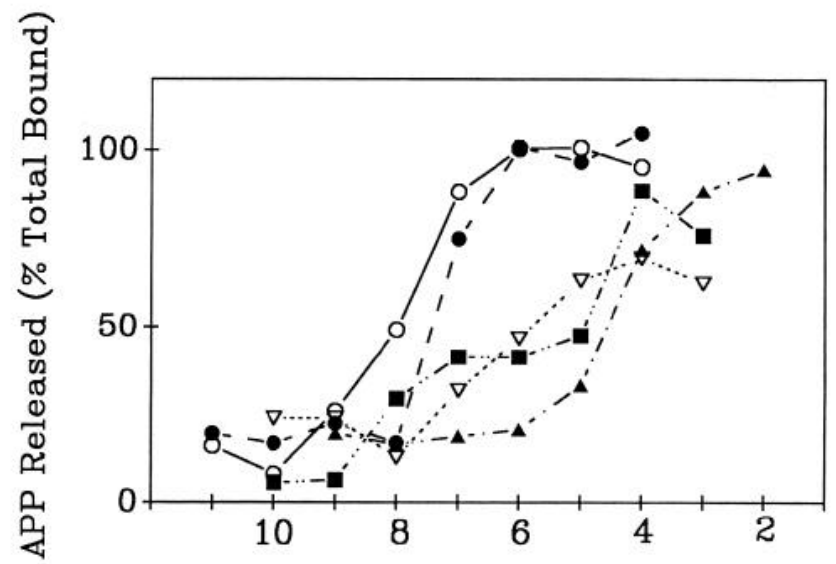

- $\log$ (Concentration of Protease, $\mathrm{gm} / \mathrm{ml}$ )

Figure 6. Release of ${ }^{125}$ I-APP from embryonic chick brain ECM by fetal bovine serum AChE-AP $(\bullet)$, eel AChE-AP (O), trypsin (४), plasmin $(\nabla)$, and thrombin $(\square)$. Iodinated APP was incubated with ECM. The ECM was washed with phosphate-buffered saline and then incubated with the protease for $1 \mathrm{hr}$ at $37^{\circ} \mathrm{C}$. Each point represents the mean of two determinations. The experiment was performed four times with similar results. The variation between duplicate values was less than $10 \%$. One hundred percent bound represented $642 \mathrm{cpm}$ of ${ }^{125}$ I-APP bound/well.

release of APP from ECM was due to its trypsin-like protease activity.

\section{Discussion}

This study demonstrates that APP binds saturably to one or more components of chick brain ECM with an equilibrium dissociation constant $\left(K_{d}\right)$ of 60 nM. APP possesses a specific heparin binding site (Schubert et al., 1989b) and may therefore bind several heparan sulfate proteoglycans. In a study by $\mathrm{Na}$ rindrasorasak et al. (1991), it was concluded that APP could bind to both the protein core and glycan moiety of a proteoglycan purified from Engelbreth-Holm-Swarm tumor.

To study the possibility that APP may also bind to ECM components of CNS origin, we examined the binding of APP to chick brain ECM and the effect of inhibitors of proteoglycan biosynthesis on binding. The finding that xyloside and chlorate pretreatment of cells resulted in $80 \%$ loss of APP binding sites indicates that at least $80 \%$ of the APP binding sites may be

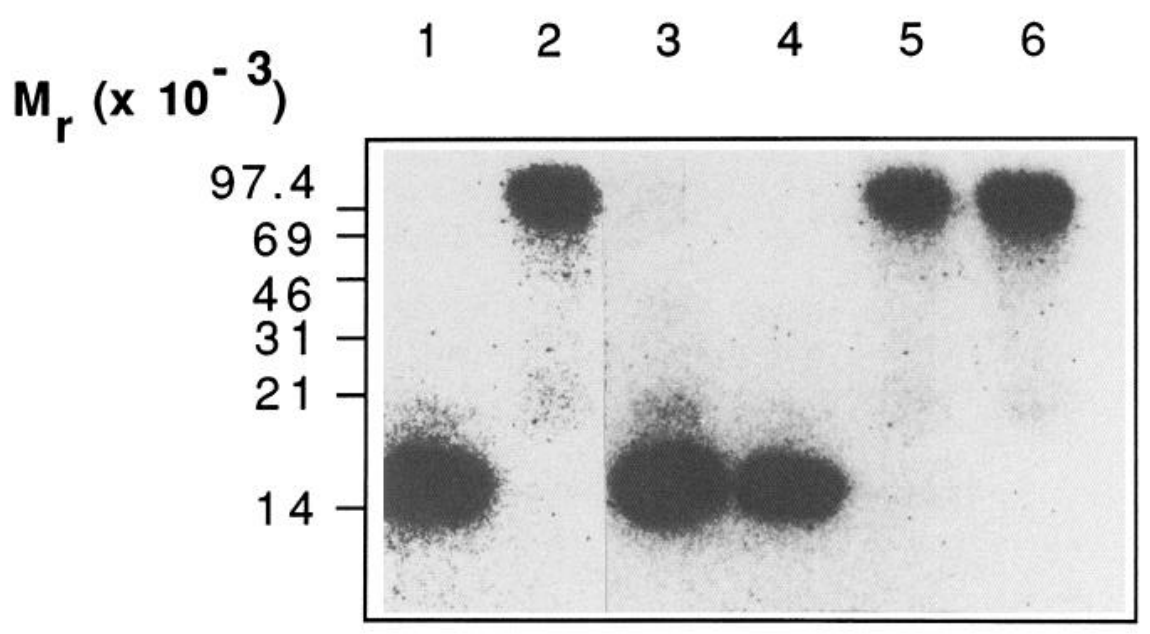

Figure 5. Autoradiogram of ${ }^{125} \mathrm{I}-\mathrm{la}$ beled APP and acidic FGF analyzed by SDS-PAGE. Labeled proteins were separated on a $15 \%$ polyacrylamide gel. The figure shows that the labeled proteins released from embryonic chick brain ECM by incubation for $1 \mathrm{hr}$ with the AChE-AP $(10 \mu \mathrm{g} / \mathrm{ml})$ have an $M_{r}$ similar to the protein prior to incubation. Lanes 1 and 2, Iodinated proteins prior to binding experiment. Lanes 3-6, Labeled proteins released by AChE-AP purified from fetal bovine serum (lanes 3 and 5) and eel electroplax (lanes 4 and 6). Experiments were performed using either ${ }^{125}$ I-acidic FGF (lanes 1,3,4, ) or ${ }^{125}$ I-APP (lanes 2,5,6). Each lane contained approximately $500-1000 \mathrm{cpm}$ of ${ }^{125}$ I-APP bound/well. 


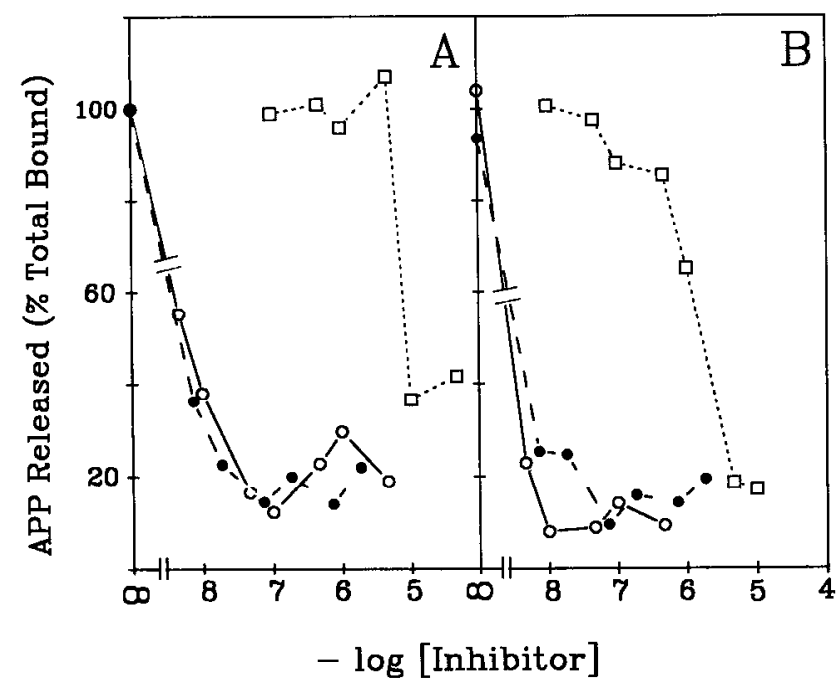

Figure 7. Effect of human brain APP (0), recombinant PN I (๑), and soybean trypsin inhibitor $(\square)$ on the release of iodinated APP from embryonic chick brain ECM by incubation for $1 \mathrm{hr}$ with AChE-AP (1 $\mu \mathrm{g} / \mathrm{ml}$ ) purified from fetal bovine serum $(A)$ or eel electroplax $(B)$. Each point represents the mean of two determinations. The experiment was performed twice with very similar results. The variation between duplicate values in this experiment was less than $10 \%$. One hundred percent bound represented $625 \mathrm{cpm}$ of ${ }^{125}$ I-APP bound/well.

associated with ECM proteins. It is unlikely that the $20 \%$ of binding sites remaining after xyloside or chlorate treatment were due to proteoglycans synthesized prior to treatment, as cells were cultured for only a short period $(2 \mathrm{~d})$ until confluent prior to the addition of inhibitor. Furthermore, maximum ECM production is normally only achieved once cells have reached confluency.

The proteins that bind APP in the brain ECM are not yet known. Acidic and basic FGF are known to bind to the glycan component of certain heparan sulfate proteoglycans (see Klagsbrun and Baird, 1991, for a recent review). Heparitinase pretreatment of ECM decreased the binding of APP by $80 \%$, suggesting that APP may also bind to proteoglycans. Our results are consistent with the studies of Narindrasorasak et al. (1991), who showed that APP can bind tightly $\left(K_{d}=10 \mathrm{nM}\right)$ to a heparan sulfate proteoglycan, an interaction that was weakly inhibited by heparin. We observed that heparin and heparan sulfate did not inhibit binding of APP to ECM at concentrations up to 10 $\mu \mathrm{g} / \mathrm{ml}$. This lack of inhibition is probably due to the presence of heparan sulfate binding sites on ECM, which could compete with APP for heparan sulfate binding.

Studies on the expression of AChEs in embryonic tissues have provided evidence for the view that $\mathrm{AChE}$ has functions other than the hydrolysis of ACh at cholinergic synapses (Layer, 1983). During the early stages of embryonic development in the chick, AChE activity is expressed at stages in which cell proliferation ceases and neurons begin to differentiate. The present study confirms that levels of $\mathrm{AChE}$ begin to increase in the chick brain at the major period of neurite outgrowth (embryonic day 7). At this stage, levels of APP also increase dramatically in the embryonic brain.

A protease associated with preparations of $\mathrm{AChE}$ from eel electric organ or fetal bovine serum was found to release APP and acidic FGF from ECM. The AChE-AP was distinguished from other trypsin-like proteases by its lack of interaction with

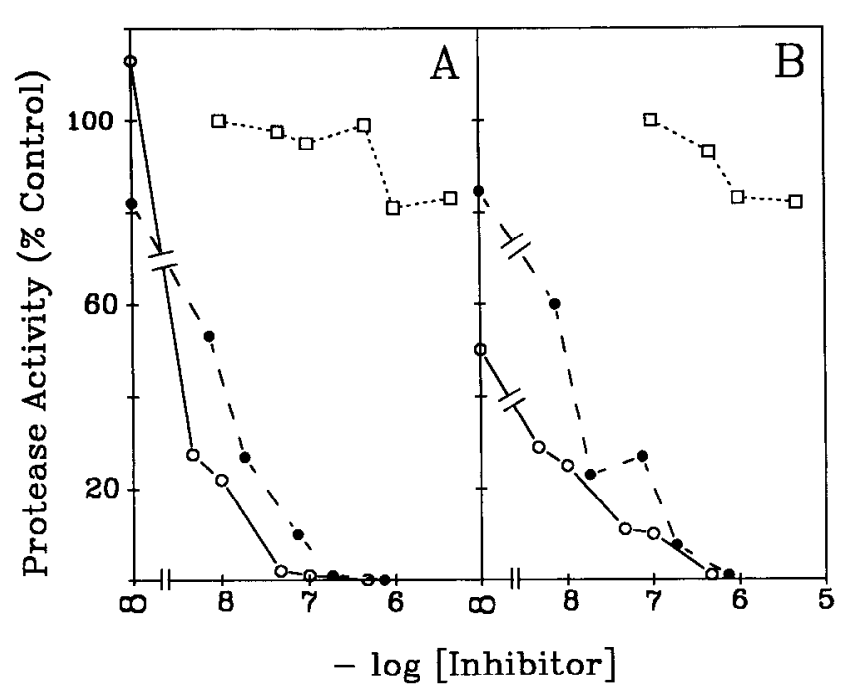

Figure 8. Effect of human brain APP (O), recombinant PN I (O), and soybcan trypsin inhibitor $(\square)$ on the AChE-AP $(1 \mu \mathrm{g} / \mathrm{ml})$ from fetal bovine serum $(A)$ or eel electroplax $(B)$ as measured by the cleavage of a model peptide substrate (Small et al., 1987). Protease activity was defined as the amount of model peptide (Leu-Trp-Met-Arg-Phe-Ala) cleaved to its tryptic fragment (Leu-Trp-Met-Arg) for $1 \mathrm{hr}$ at $37^{\circ} \mathrm{C}$. Approximately $10 \mathrm{ng}$ of model peptide was hydrolyzed per hour per microgram of protein.

benzamidine-Sepharose, its low sensitivity to inhibition by soybean trypsin inhibitor, and its association with AChE through several purification steps. The AChE-AP released acidic FGF and APP intact from the matrix, presumably by acting upon an ECM component that either directly or indirectly binds acidic FGF or APP. The specificity of the action of the AChE-AP on ECM is supported by the finding that other proteases (plasmin, thrombin), previously implicated for their actions on ECM, were approximately 100 -fold less potent than the partially purified preparations of AChE-AP in their ability to release APP from the ECM. Further evidence for the specificity of this effect comes from the finding that PN I and purified human brain APP itself potently inhibited the release of APP by the AChE-AP from the ECM.

Our study leaves open the question of whether a protease activity is associated with $\mathrm{AChE}$ in the chick brain. In a previous study (Small et al., 1991), we found that a protease activity similar to that associated with eel or bovine serum AChE was recovered in a preparation of 400,000 -fold-purified human brain $\mathrm{AChE}$. As AChE comprises as little as $0.001 \%$ of the total protein in most vertebrate brains (Silman, 1984), a direct demonstration of the presence of a protease activity associated with chick brain AChE must await the complete purification of the protease and the generation of antibodies that specifically recognize it.

We have shown that the protease activity associated with AChE purified from eel electroplax organ or fetal bovine serum can act as an "APP secretase" to cleave the transmembrane form of APP from cells, thereby releasing a soluble form of the protein that is C-terminally truncated (Small et al., 1991). Secreted forms of APP may bind to components of the ECM such as heparan sulfate proteoglycans (Klier et al., 1990). Our studies suggest that the AChE-AP may act not only to increase the secretion of APP from the surface of cells (Small et al., 1991) but also to release bound forms of APP from ECM.

Both APP and PN I were found to inhibit the ability of the AChE-AP to release APP from ECM. PN I is an inhibitor of 
serine proteases such as thrombin and urinary plasminogen activator (urokinase) (Baker et al., 1980) and has been shown to promote neurite outgrowth from cultured sympathetic neurons (Zurn et al., 1988) and hippocampal pyramidal cells (Farmer et al., 1990). Certain forms of APP produced by alternative mRNA splicing possess a domain that shares approximately $50 \%$ amino acid sequence similarity to the Kunitz family of protease inhibitors (KPI). The levels of KPI-containing forms of APP may be important in the pathogenesis of Alzheimer's disease. Studies by Quon et al. (1991) suggest that overexpression of KPI-containing forms of APP in transgenic mice leads to an amyloid deposition similar to that seen in Alzheimer's disease. KPIcontaining forms of APP may bind proteases and inhibit their action (Sinha et al., 1990). If KPI-containing forms of APP inhibit proteases involved in cell-ECM intereactions, then APP may also be involved in regulating cell growth and adhesion. The present study suggests that the release of APP or other factors from ECM by proteases might be inhibited by APP. Thus, KPI-containing forms of APP may have subtle actions on neurite outgrowth or cell differentiation by regulating the availability of growth factors bound to the ECM.

\section{References}

Baker JB, Low DA, Simmer RL, Cunningham DD (1980) Proteasenexin: a cellular component that links thrombin and plasminogen activator and mediates their binding to cells. Cell 21:37-45.

Barthalay Y, Hipeau-Jacquotte R, De la Escalera S, Jimenez F, Piovant M (1990) Drosophila neurotactin mediates heterophilic cell adhesion. EMBO J 9:3603-3609.

Bergman BL, Scott RW, Bajpai A, Watts S, Baker JB (1986) Inhibition of tumor-cell-mediated extracellular matrix destruction by a fibroblast proteinase inhibitor, protease nexin I. Proc Natl Acad Sci USA 83: 996-1000.

Bon S, Méflah K, Musset F, Grassi J, Massoulié J (1987) An immunoglobulin $\mathrm{M}$ monoclonal antibody, recognizing a subset of acetylcholinesterase molecules from electric organs of Electrophorus and Torpedo, belongs to the HNK-1 anti-carbohydrate family. J Neurochem 49:1720-1731.

Bradford MM (1976) A rapid and sensitive method for the quantitation of microgram quantities of protein utilizing the principle of protein-dye binding. Anal Biochem 72:248-254

Bush AI, Martins RN, Rumble B, Moir R, Fuller S, Milward E, Currie J, Ames D, Weidemann A, Fischer P, Multhaup G, Bcyrcuther K, Masters CL (1990) The amyloid precursor protein of Alzheimer's disease is released by human platelets. J Biol Chem 265:15977-15983.

Carey DJ, Rafferty CM, Todd MS (1987) Effects of inhibition of proteoglycan synthesis on the differentiation of cultured rat Schwann cells. J Cell Biol 105:1013-1021.

De la Escalara S, Bockamp E-O, Moya F, Piovant M, Jiménez F (1990) Characterization and gene cloning of neurotactin, a Drosophila transmembrane protein related to the cholinesterases. EMBO J 9:35933601.

Ellman GL, Courtney KD, Andres V, Featherstone RM (1961) A new and rapid colorimetric determination of acetylcholinesterase activity. Biochem Pharmacol 7:88-95.

Farmer L, Sommer J, Monard D (1990) Glia-derived nexin potentiates neurite extension in hippocampal pyramidal cells in vitro. Dev Neurosci 12:73-80.

Flaumenhaft R, Moscatelli D, Saksela O, Rifkin DB (1989) The role of extracellular matrix in the action of basic fibroblast growth factor: matrix as a source of growth factor for long-term stimulation of plasminogen activator production and DNA synthesis. J Cell Physiol 140: 75-81.

Gloor S, Odink K, Guenther J, Nick H, Monard D (1986) A gliaderived neurite promoting factor with protease inhibitory activity belongs to the protease nexins. Cell 47:687-693.

Guenther J, Nick H, Monard D (1985) A glia-derived neurite promoting factor with protease inhibitory activity. EMBO J 4:19631966.
Hassell JR, Robey PG, Barrach H-J, Wilczek J, Rennard SI, Martin GR (1980) Isolation of a heparan sulfate-containing proteoglycan from basement membrane. Proc Natl Acad Sci USA 77:4494-4498.

Hunter WM, Greenwood FC (1962) Preparation of iodine-131 labeled human growth hormone of high specific activity. Nature 194:495496.

Klagsbrun M, Baird A (1991) A dual receptor system is required for basic fibroblast growth factor activity. Cell 67:229-231.

Klier FG, Cole G, Stallcup W, Schubert D (1990) Amyloid $\beta$-protein precursor is associated with extracellular matrix. Brain Res 515:336342.

Krejci E, Duval N, Chatonnet A, Vincens P (1991) Cholinesteraselike domains in enzymes and structural proteins: functional and evolutionary relationships and identification of a catalytically essential aspartic acid. Proc Natl Acad Sci USA 88:6647-6651.

Krystosek A, Seeds NW (1981a) Plasminogen activator secretion by granule neurons in cultures of developing cerebellum. Proc Natl Acad Sci USA 78:7810-7814.

Krystosek A, Seeds NW (1981b) Plasminogen activator release at the neuronal growth cone. Science 213:1532-1534.

Krystosek A, Seeds NW (1984) Peripheral neurons and Schwann cells secrete plasminogen activator. J Cell Biol 98:773-776.

Laemmli UK (1970) Cleavage of structural proteins during the assembly of the head of bacteriophage T4. Nature 227:680-685.

Layer PG (1983) Comparative localization of acetylcholinesterase and pseudocholinesterase during morphogenesis of the chicken brain. Proc Natl Acad Sci USA 80:6413-6417.

Layer PG, Alber R, Sporns O (1987) Quantitative development and molecular forms of acetyl- and butyrylcholinesterase during morphogenesis and synaptogenesis of chick brain and retina. J Neurochem 49:175-182.

Layer PG, Rommel S, Bülthoff H, Hengstenberg R (1988) Independent spatial waves of biochemical differentiation along the surface of chicken brain as revealed by the sequential expression of acetylcholinesterase. Cell Tissue Res 251:587-595.

McGrogan M, Kennedy M, Li MP, Hsu C, Scott RW, Simonsen CC, Baker JB (1988) Molecular cloning and expression of two forms of human protease nexin I. Biotechnology 6:172-177.

Moir RD, Martins RN, Bush AI, Small DH, Milward EA, Rumble BA, Multhaup G, Beyreuther K, Masters CL (1992) Human brain $\beta A_{4}$ amyloid protein precursor (APP) of Alzheimer's disease: purification and partial characterization. $J$ Neurochem, in press.

Monard D (1987) Role of protease inhibition in cellular migration and neuritic growth. Biochem Pharmacol 36:1389-1392.

Monard D (1988) Cell-derived proteases and protease inhibitors as regulators of neurite outgrowth. Trends Neurosci 11:541-544.

Narindrasorasak S, Lowery D, Gonzalez-DeWhitt P, Poorman RA, Greenberg B, Kisilevsky R (1991) High affinity interactions between the Alzheimer's $\beta$-amyloid precursor protein and the basement membrane form of heparan sulfate proteoglycan. J Biol Chem 266:1287812883.

Oakley BR, Kirsch DR, Morris NR (1980) A simplified ultrasensitive silver stain for detecting proteins in polyacrylamide gels. Anal Biochem 105:361-363.

Olson PF, Fessler LI, Nelson RE, Stern RE, Campbell AG, Fessler JH (1990) Glutactin, a novel Drosophila basement membrane-related glycoprotein with sequence similarity to serine esterases. EMBO J 9: 1219-1227.

Oltersdorf T, Fritz LC, Schenk DB, Lieberburg I, Johnson-Wood KL, Beattie EC, Ward PJ, Blacher RW, Dovey HF, Sinha HF (1989) The secreted form of the Alzheimer's amyloid precursor protein with the Kunitz domain is protease nexin-II. Nature 341:144-147.

Perris R, Bronncr-Frascr M (1989) Recent advances in defining the role of the extracellular matrix in neural crest development. Comments Dev Neurobiol 1:61-83.

Pittman RN (1985) Release of plasminogen activator and a calciumdependent metalloprotease from cultured sympathetic and sensory neurons. Dev Biol 110:91-101.

Quon D, Wang Y, Catalana R, Scardina JM, Murakami K, Cordell B (1991) Formation of $\beta$-amyloid protein deposits in brains of transgenic mice. Nature 352:239-241.

Rapraeger AC, Krufka A, Olwin BB (1991) Requirement of heparan sulfate for bFGF-mediated fibroblast growth and myoblast differentiation. Science 252:1705-1708.

Rovelli G, Stone SR, Preissner KT, Monard D (1990) Specific inter- 
action of vitronectin with the cell-secreted protease inhibitor gliaderived nexin and its thrombin complex. Eur J Biochem 192:797803.

Saskela O, Rifkin DB (1990) Release of basic fibroblast growth factorheparan sulfate complexes from endothelial cells by plasminogen activator-mediated proteolytic activity. J Cell Biol 110:767-775.

Saskela O, Moscatelli D, Sommer A, Rifkin DB (1988) Endothelial cell-derived heparan sulfate binds basic fibroblast growth factor and protects it from proteolytic degradation. J Cell Biol 107:743-751.

Schubert D, Jin L-W, Saitoh T, Cole G (1989a) The regulation of amyloid $\beta$ protein precursor secretion and its modulatory role in cell adhesion. Neuron 3:689-694.

Schubert D, LaCorbiere M, Saitoh T, Cole G (1989b) Charactcrization of an amyloid $\beta$ precursor protein that binds heparin and contains tyrosine sulfate. Proc Natl Acad Sci USA 86:2066-2069.

Silman I (1984) Molecular properties and biosynthesis of acetylcholinesterase. In: Molecular biology approach to the neurosciences (Soreq $\mathrm{H}$, ed), pp 53-57. Chichester: Wiley.

Sinha S, Dovey HF, Seubert P, Ward PJ, Blacher RW, Blaber M, Bradshaw RA, Arici M, Mobley WC, Lieberburg I (1990) The protease inhibitory properties of the Alzheimer's $\beta$-amyloid precursor protein. J Biol Chem 265:8983-8985.

Small DH (1988) Serum acetylcholinesterase possesses trypsin-like and carboxypeptidase B-like activity. Neurosci Lett 95:307-312.

Small DH (1990) Non-cholinergic actions of acetylcholinesterases: proteases regulating cell growth and development? Trends Biochem Sci 15:213-216.
Small DH, Ismael Z, Chubb IW (1987) Acetylcholinesterase exhibits trypsin-like and metalloexopeptidase-like activity in cleaving a model peptide. Neuroscience 21:991-995.

Small DH, Moir RD, Fuller SJ, Michaelson S, Bush AI, Li Q-X, Milward E, Hilbich C, Weidemann A, Beyreuther K, Masters CL (1991) A protease activity associated with acetylcholinesterase releases the membrane-bound form of the amyloid protein precursor of Alzheimer's disease. Biochemistry 30:10795-10799.

Sommer J, Meyhack B, Rovelli G, Buergi R, Monard D (1989) Synthesis of glia-derived nexin in yeast. Gene 85:453-459.

Van Nostrand WE, Wagner SL, Suzuki M, Choi BH, Farrow JS, Geddes JW, Cotman CW, Cunningham DD (1989) Protease nexin-II, a potent antichymotrypsin, shows identity to amyloid $\beta$-protcin prccursor. Nature 341:546-549.

Vlodavsky I, Bar-Shavit R, Ishai-Michaeli R, Bashkin P, Fuks Z (1991) Extracellular sequestration and release of fibroblast growth factor: a regulatory mechanism? Trends Biochem Sci 16:268-271.

Weidemann A, Konig G, Bunke D, Fischer P, Salbaum JM, Masters CL, Beyreuther K (1989) Identification, biogenesis and localization of precursors of Alzheimer's disease $A_{4}$ amyloid protein. Cell 57:1 15126.

Zurn AD, Nick H, Monard D (1988) A glia-derived nexin promotes neurite outgrowth in cultured chick sympathetic neurons. Dev Neurosci $10: 17-24$ 